\title{
Structure and thermal properties of microcrystalline cellulose extracted from coconut husk fiber
}

\author{
Nur Athirah Abdullah ${ }^{1)}$ (oRcid ID: 0000-0002-2239-6152), Muhammad Hanif Sainorudin ${ }^{1)}$ (o000-0002-9177-5906), \\ Mohd Saiful Asmal Rani ${ }^{1), *)}$ (0000-0002-3909-1259), Masita Mohammad ${ }^{1), *)}$ (0000-0002-5573-7048),

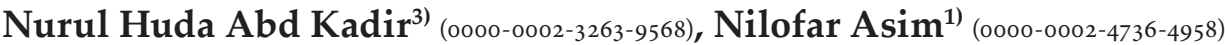

DOI: dx.doi.org/10.14314/polimery.2021.3.4

\begin{abstract}
In this work, chemically treated microcrystalline cellulose (MCC-C) was extracted from coconut husk fiber. In order to extract hemicellulose, the sieved coconut husk fiber was treated with sodium hydroxide $(\mathrm{NaOH})$ for dewaxing and acidified using sodium chlorite $\left(\mathrm{NaClO}_{2}\right)$ to extract the residual lignin (bleaching process). The obtained lignin-free cellulose was then treated with potassium hydroxide $(\mathrm{KOH})$. The characterizations used to equate the MCC-C with commercial grade microcrystalline cellulose (MCC) are solubility test, X-ray diffractogram (XRD), thermogravimetric analysis (TGA) and scanning electron microscopy (SEM). The XRD showed that the crystallinity of MCC and MCC-C increased significantly by $80.15 \%$ and $71.8 \%$ by chemical treatments. TGA found that the active removal of lignin-hemicelluloses and the thermal stability of the material were about $350-500^{\circ} \mathrm{C}$ and $300-500^{\circ} \mathrm{C}$. The morphology of the fiber confirmed that there is an irregular cross-section, non-uniform surface, a large amount of short microfibrils and some impurities on the surface of the coconut husk fiber. The findings showed that microcrystalline cellulose has been successfully extracted from coconut husk fiber and that it can be used further.
\end{abstract}

Keywords: microcrystalline cellulose, coconut husk, chemical treatment.

\section{Struktura i właściwości termiczne celulozy mikrokrystalicznej pozyskiwanej z włókien łupiny orzecha kokosowego}

\begin{abstract}
Streszczenie: Celulozę mikrokrystaliczną (MCC-C) wyekstrahowaną z włókien łupiny orzecha kokosowego poddano obróbce chemicznej. Na przesiane włókna łupin orzecha kokosowego działano roztworem wodorotlenku sodu $(\mathrm{NaOH})$ w celu usunięcia wosku, następnie zakwaszono je roztworem chlorynu(III) sodu $\left(\mathrm{NaClO}_{2}\right)$, w celu ekstrakcji resztkowej ligniny (proces bielenia). Na otrzymaną, pozbawioną ligniny celulozę działano wodorotlenkiem potasu $(\mathrm{KOH})$. Porównano uzyskaną MCC-C z handlową celulozą mikrokrystaliczną (MCC) na podstawie przeprowadzonego testu rozpuszczalności, badań metodami dyfrakcji rentgenowskiej (XRD), analizy termograwimetrycznej (TGA) i skaningowej mikroskopii elektronowej (SEM). Wyniki badań XRD wykazały, że po obróbce chemicznej krystaliczność zarówno MCC, jak i MCC-C zwiększyła się istotnie o, odpowiednio, 80,15\% i 71,8\%. Wyniki badań TGA wykazały, że aktywne usunięcie lignin-hemiceluloz powoduje zwiększenie stabilności termicznej celulozy mikrokrystalicznej i przesunięcie temperatury rozkładu do zakresu, odpowiednio, $350-500^{\circ} \mathrm{C}$ i $300-500^{\circ} \mathrm{C}$. Analiza morfologii włókien potwierdziła ich nieregularny przekrój poprzeczny, niejednorodną powierzchnię, dużą liczbę krótkich mikrofibryli oraz zanieczyszczenia na powierzchni. Stwierdzono, że celuloza mikrokrystaliczna wyekstrahowana z włókien łupiny orzecha kokosowego nadaje się do wykorzystania.
\end{abstract}

Słowa kluczowe: celuloza mikrokrystaliczna, łupina orzecha kokosowego, obróbka chemiczna.

Wood, cotton, hemp and other plant-based materials are constituted from cellulose, which is known as one of the most plentiful biopolymers on earth and the main reinforcement element in the structure of plants. Their application in composite materials has gained growing consideration because of their weight, biodegradability

\footnotetext{
1) Universiti Kebangsaan Malaysia, Solar Energy Research Institute (SERI), 43600 Bangi, Selangor, Malaysia.

2) National Defence University of Malaysia, Centre for Tropicalisation, Kem Sungai Besi, 57000 Kuala Lumpur.

3) Universiti Malaysia Terengganu, School of Fundamental Sciences, 21030 Kuala Nerus, Terengganu, Malaysia.

*) Authors for correspondence: iker.asmal55@gmail.com; masita@ukm.edu.my
} 
and renewability [1]. From many agricultural wastes, such as sugarcane bagasse, wood, cotton, pineapple leaves and coconut husk cellulose can be extracted. Coconut husk is a coconut residue, and it is produced every year in large quantities. Tones of unused agro-industrial waste are produced annually, with only a small percentage being used as feedstock for energy production [2]. Because of its biodegradable and reusable structural plant polymers, cellulose can be transformed into whisker-like microfibrils, microcrystalline cellulose (MCC), nanocrystalline cellulose (NCC) and many more [3]. To solve these issues, a strong call for renewable energy sources has been launched worldwide. The increasing use of renewable energy sources (wind, solar, etc.) faces many key challenges, including the modulation from time to time of variable renewable resources, the smooth incorporation into the grid and the balancing of electricity generation and demand in peak and off-peak times [4].

Coconut husk is the mild, fluffy material that comes off coconut (Cocos nucifera L.) fruit from thick mesocarp when its miles are shredded during the processing of husk [5]. By their nature, coconut residues are a lignocellulosic material with renewable, biodegradable and biocompatible characteristics, and can be a valuable resource for natural fiber as a perfect raw material [6]. One of the agricultural waste products from the processing of coconut oil is coconut husk fiber, which belongs to the palm fiber family, and can be obtained in the tropical regions of the world, especially in South America, Africa and Asia. Coconut husk fiber can be obtained in Malaysia in large amounts. The fiber was obtained by removing a coconut from the outer shell [7]. The key content of coconut husk fiber [8] is cellulose, hemicellulose and lignin. The effects of many synthetic polymers and biodegradable polymers, agar, starch, cellulose, chitin, chitosan and carrageenin, due to their natural resources, plentiful availability, biodegradability and low cost, are now attracting great attention due to a lot of risk to our climate [9]. Cellulose is an abundant and naturally occurring element with good mechanical properties. Cellulose is not soluble in water in its native form. A chemical reaction of its hydroxyl groups with a hydrophilic substituent will rectify this [10]. Despite its relative chemical simplicity, the physical and morphological structure of native cellulose in taller plants is complex and heterogeneous. In addition, in plant cell walls, more complex morphologies of cellulose molecules are familiarly correlated with other polysaccharides and lignin [11]. Chemical treatments consisting of alkali extraction and bleaching have also been used in plant fiber cellulose purification [12]. In order to improve the compatibility of natural fiber, several treatment methods have been accomplished. The procedure seeks to change the surface of the fiber physically and chemically. Figure 1 illustrates the schematic principle of isolation process from cellulosic plant fiber to cellulose fiber.

The factors influencing the improvement of the properties of natural fibers [13] are surface geometry, soil drainage, fiber consistency and contact between the fiber and the base and the framework. Treatment with alkali on natural fibers is also used as part of chemical treatment. Alkali treatment depends on the evacuation of a significant proportion of alkali hemicelluloses, lignin, waxes and oils, resulting in a rough fiber surface due to decreased fiber aggregation [14]. Studies on chemical treatment of coconut fiber have

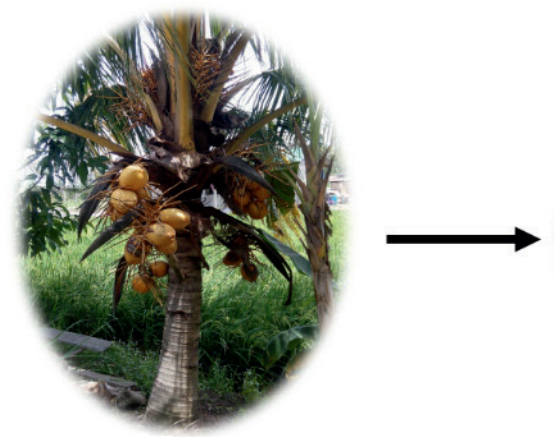

Coconut tree

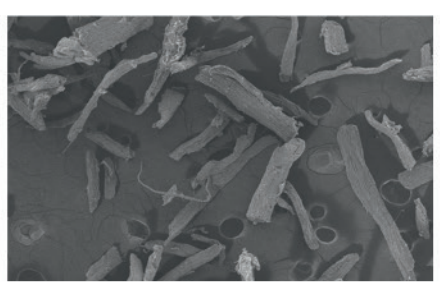

SEM micrograph of MMC

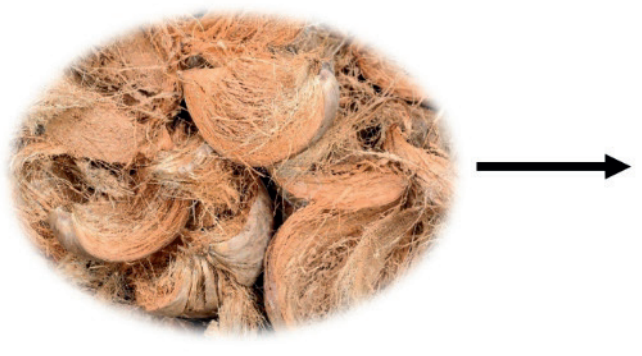

Coconut husk

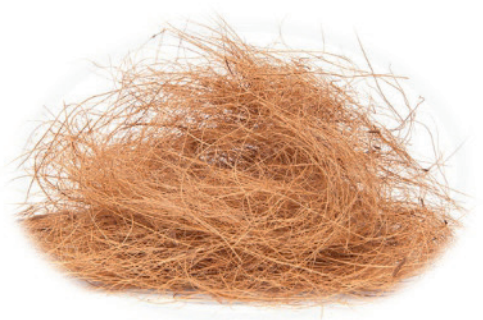

Coconut husk fibers

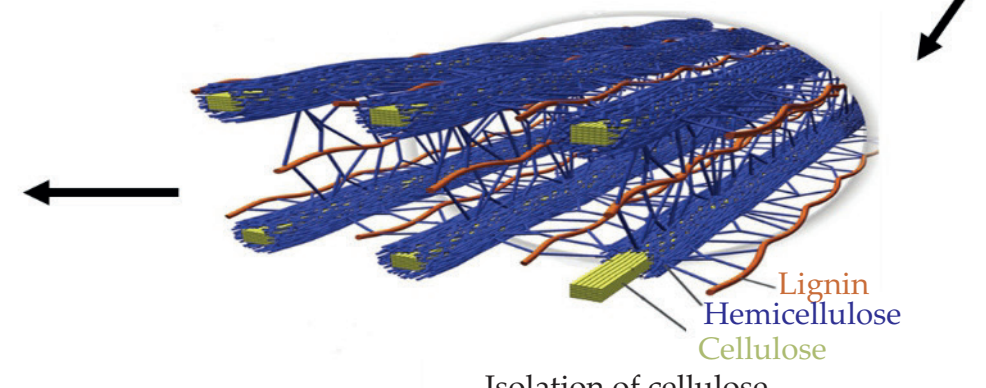

Isolation of cellulose

Fig. 1. Schematic principle of isolation process cellulose fiber from cellulosic plant 
been performed by researchers [14-16], but to the best of our knowledge there is no literature study using coconut husk fiber as the key material for the development of MCC. The physical and chemical properties of cellulose and its chemical reactivity and behavior were highly affected by the arrangement of the hydroxyl group and hydrogen bonding with respect to each other and to the fiber axis. Sequences of its native cellulose organize the amorphous region and the crystalline region. It is possible to eliminate the amorphous region and isolate the crystalline region when it undergoes a chemical reaction [17]. Low cost, low density, comparable basic tensile properties, non-abrasive to the machinery, non-irritating to the skin, reduced energy consumption, less health risk, renewability, recyclability and biodegradability are the various advantages of cellulose from natural fibers over man-made cellulose. The current scientific focus is more on cellulose biosynthesis because of the great economic importance of cellulose, as it is still not well understood. Few researches were done on comparing the properties and morphology of coconut husk fiber using chemical treatment with commercial grade of MCC. Thus, this work focuses on the extraction of coconut husk fiber by using alkaline and bleaching treatment of MCC from coconut husk fiber, followed by empirical study of its properties and comparison to the commercial grade of MCC.

\section{EXPERIMENTAL PART}

\section{Materials}

The coconut husk fibers were collected from the local agricultural farm, Sabak Bernam, Malaysia. A total of 2 bags, or $3 \mathrm{~kg}$ of sample weight, were collected in this study. Reagent grade chemicals were obtained from R\&M Chemicals Ltd. (United Kingdom) for fiber surface modifications and bleaching, namely toluene, ethanol, potassium hydroxide and sodium chlorite. For purposes of contrast, industrial microcrystalline cellulose (MCC) R\&M Chemicals Ltd. (United Kingdom) was used. Without any further purification, these pure and analytical grade chemicals were used directly.

\section{Isolation of microcrystalline cellulose from agricultural waste}

\section{Pre-treatment of MCC-C}

In this study, coconut husk fibers cut into small parts before were blended using grinder machine. The husk was washed repeatedly with water and dried for $18 \mathrm{~h}$ in a temperature-controlled oven at $60^{\circ} \mathrm{C}$. The sample was held in an airtight bag and, before further analysis, put in a desiccator.

\section{Preparation of MCC-C}

The process used for the extraction of microcrystalline cellulose was based on [18] with a slight modifications. The fiber was dewaxed in the Soxhlet system with toluene-etha$\operatorname{nol}(2: 1, \mathrm{v} / \mathrm{v})$ and then dried in an oven at $60^{\circ} \mathrm{C}$. Dried coconut husk samples $(5 \mathrm{~g})$ were first kept at $70^{\circ} \mathrm{C}$ for $1 \mathrm{~h}$ with sodium chlorite $\left(\mathrm{NaClO}_{2}\right)$ (acetic acid was used to achieve $\mathrm{pH} 4$ ), and this process was repeated until the sample turned white. At $70-80^{\circ} \mathrm{C}$, heating persisted for $2 \mathrm{~h}$. Then, it was filtered until the $\mathrm{pH}$ was neutral to eliminate water-soluble components and washed. The residue was then treated at room temperature overnight using potassium hydroxide (6 wt \%). Cellulose was washed carefully with distilled water after filtration and dried in an oven for $16 \mathrm{~h}$ at $40^{\circ} \mathrm{C}$. Cellulose that was dried was preserved for further use.

\section{Methods of testing}

\section{Chemical composition analysis}

The chemical composition of MCC-C and commercial MCC was determined by its moisture, hemicellulose, cellulose and lignin while its solubility test were determined by using distilled water (DI), sodium hydroxide $(\mathrm{NaOH})$, hydrochloric acid $(\mathrm{HCl})$ and acetone content.

\section{Structural analysis}

To test the crystallinity of the samples, XRD (D8-Advance Bruker AXS GmbH) was performed with a monochromatic $\mathrm{CuK}$ radiation source $(0.1539 \mathrm{~nm})$ at room temperature (RT) in step-scan mode with a period of 2 of $5.0 \mathrm{~min}$. The material crystallinity index was measured using the peak height method, which is the most common and easy method of calculating the degree of crystallinity as an analytical method. To measure the crystallinity of the samples, the crystallinity index value was computed. The index of crystallinity (CI) is defined by [19]:

$$
\mathrm{CI}(\%)=I_{\text {cry }}-I_{\text {ams }} / I_{\text {cry }}
$$

where: CI - the crystallinity index (\%), $I_{\text {cry }}$ - the maximum intensity at $2 \theta, I_{\text {ams }}$ - the intensity of the amorphous substance at an angle between the peaks in the valley [20].

$$
\text { Crystallite size (nm) } D=\mathrm{k} \lambda / \beta \cos \theta
$$

where: $D$ - diameter or mean size of the ordered (crystalline) domains, $\mathrm{k}$ - the Scherrer's constant (0.94), $\lambda$ - the wavelength of the $X$-ray radiation, $\beta$ - the full width of the diffraction peak at the half limit (FWHM), $\theta$ - the corresponding Bragg's angle.

\section{Thermogravimetric analysis}

To determine the degradation features of the samples, TGA was performed. Using a Perkin Elmer Thermal Analyser (Waltham, MA, USA) the thermostability of the sample prepared was analysed. Approximately $16 \mathrm{mg}$ of the sample were heated from room temperature to $800^{\circ} \mathrm{C}$ 
under nitrogen atmosphere with a gas flow $\left(60 \mathrm{~cm}^{3} / \mathrm{min}\right)$ with a heating rate of $10^{\circ} \mathrm{C} / \mathrm{min}$. In order to determine the mass loss of the sample after heating, the percentage of residue mass was reported.

\section{Morphology studies}

Morphology experiments were conducted using the SEM (model Philips XL 30) to determine the coconut husk fiber surface morphology of the sample. Prior to SEM observation, the samples were coated before the study with gold in a plasma sputtering apparatus. The thickness of the layer of gold was roughly 0.01-0.1 nanometres. $15 \mathrm{kV}$ was the accelerating voltage.

\section{RESULTS AND DISCUSSION}

\section{Chemical composition of coconut husk fiber}

Cellulose, lignin and hemicellulose are major components of coconut husk fibers. Table 1 summarises this percentage of the chemical composition found in MCC-C.

Comparison of solubility test of microcrystalline cellulose prepared from coconut husk fiber with commercial MCC are presented in the Table 2 below.

These compositions were inspired by the different properties of coconut husk fibers. Ultimately, due to the pre-treatment of fiber modifications, the properties of coconut husk fibers have also improved [7]. The fiber surface became rough to minimise fiber aggregation due to alkali treatment and most hemicelluloses, lignin, waxes and alkali-soluble oils were required to be

$\mathrm{T}$ a b l e 1. Chemical composition of MCC-coconut husk fiber

\begin{tabular}{c|c}
\hline & Content, wt \% \\
\hline Moisture & 25.3 \\
Hemicellulose & 16.3 \\
Cellulose & 41 \\
Lignin & 31.2 \\
\hline
\end{tabular}

removed [14]. Bleaching treatment was used to complete the disposal of the residual cementing materials from the fiber. Polysaccharide, soluble in water, is a component of

$\mathrm{T}$ a b 1 e 2. Comparison of solubility tests of MCC and MCC-C

\begin{tabular}{c|c|c}
\hline Solvent & MCC-C & Commercial MCC \\
\hline Acetone & Completely & Completely \\
& insoluble & insoluble \\
Distilled water & Partially soluble & Partially soluble \\
$1 \% \mathrm{HCl}$ & Insoluble & Insoluble \\
$1 \% \mathrm{NaOH}$ & Partially soluble & Partially soluble \\
\hline
\end{tabular}

hemicellulose. The soluble character of alkali is a complex organic lignin compound. Therefore, the percentage of lignin was reduced from raw fiber to bleached fiber [21].
The MCC properties of coconut husk fibers were caused by these compositions and the pre-treatment process.

\section{Structural analysis}

XRD patterns of commercial MCC and MCC-C cellulose are shown in Fig. 2. The extracted MCC XRD spectrum reveals two peaks at $2 \theta=20^{\circ}$ in the Fig. 2 it is about $23^{\circ}$ and $15^{\circ}$ and $2 \theta=12^{\circ}$. In contrast with hemicellulose and lignin, cellulose has a well-known crystalline structure due to its hydrogen bonding and the amorphous nature of van der Waals [22]. The increase in cellulose fiber crystallinity is expected to increase its rigidity, whereas higher crystallinity is associated with higher tensile strength. Table 3 summarizes the crystallinity of the samples. The sample with successive chemical treatments has higher $I_{\text {cry }}$ values in comparison with the MCC. This is because it partly eliminates the amorphous stages such as hemicellulose and lignin by conducting the chemical procedure. Alkali treatment eliminates the amorphous sections of the plant and the material contains more crystalline cellulose regions after treatment as a result of increased crystallinity $[23,24]$.

\section{Thermogravimetric analysis}

Thermogravimetric studies are shown in Figs. 3, 4, 5 and 6. The results of the TGA also verified the successful removal of lignin and hemicelluloses and showed material thermal instability around $350-500^{\circ} \mathrm{C}$ and $300-500^{\circ} \mathrm{C}$. There was

T a b l e 3. The crystallinity of MCC and MCC-C

\begin{tabular}{c|c|c}
\hline Sample & $\begin{array}{c}\text { Crystallinity } \\
\text { index, } \%\end{array}$ & $\begin{array}{c}\text { Crystallite } \\
\text { size, } \mathrm{nm}\end{array}$ \\
\hline Commercial MCC & 80.15 & 5.08 \\
MCC-C & 71.8 & 4.47 \\
\hline
\end{tabular}

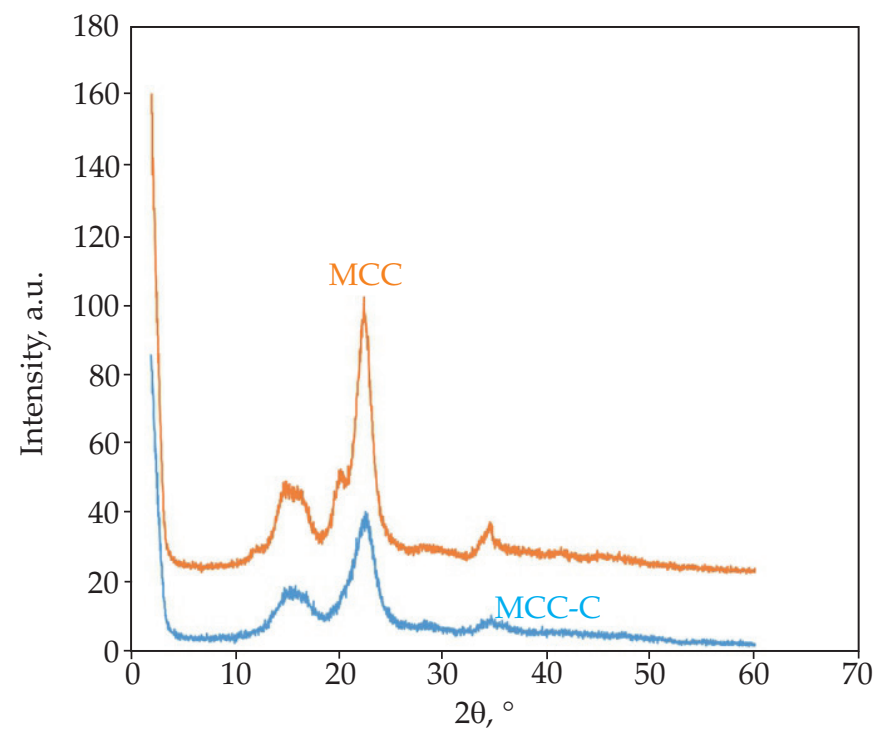

Fig. 2. XRD of the cellulose samples 


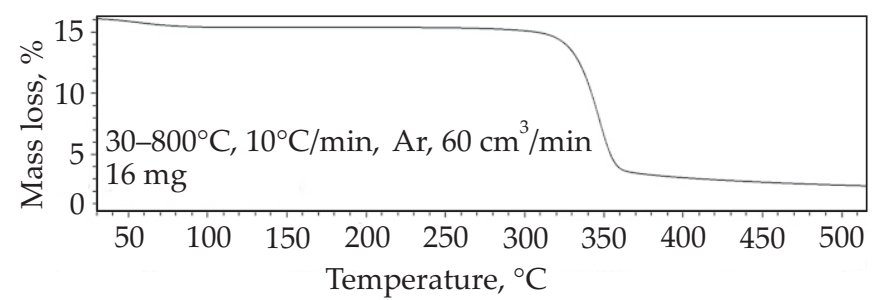

Fig. 3. TGA of the MCC

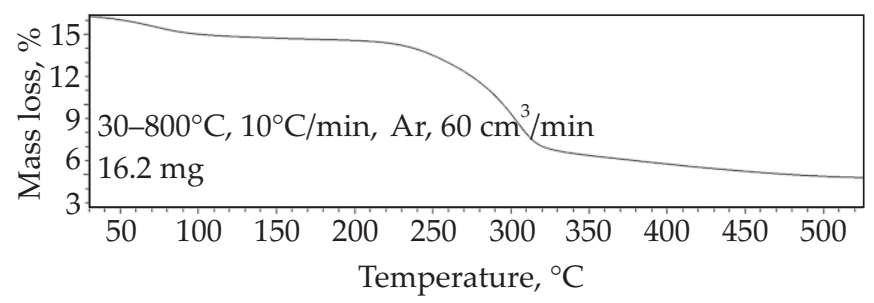

Fig. 5. TGA of the MCC-C

no noticeable mass loss in the $50-350^{\circ} \mathrm{C}$ range of the MCC (TGA) until the MCC started to degrade near $350^{\circ} \mathrm{C}$ due to cellulose degradation. At around $340^{\circ} \mathrm{C}$, the non-cellulose began to decompose, and continued to decompose until $\sim 350^{\circ} \mathrm{C}$, while at $330^{\circ} \mathrm{C}$ the fastest mass loss was observed.

The initial mass loss for MCC-C occurred marginally in the temperature range of 60 to $100^{\circ} \mathrm{C}$ [25], this is primarily due to the vaporisation and removal of bound water in the cellulose and depends on the initial fiber moisture content [24]. In the $100-240^{\circ} \mathrm{C}$ range, there was no substantial mass loss until the coconut started to degrade at around $250^{\circ} \mathrm{C}$ due to the degradation of coconut cellulose, hemicellulose and lignin. At about $270^{\circ} \mathrm{C}$, the non-cellulose in the fiber began to decompose, and continued to decompose until $\sim 320^{\circ} \mathrm{C}$, while at $290^{\circ} \mathrm{C}$, the fastest mass loss was observed.

\section{Morphology analysis}

SEM can be a valuable method for proving the morphology of coconut husk fiber and microcrystalline cellulose. SEM micrographs of the MCC and MCC-C are shown in Fig. 7.

a)

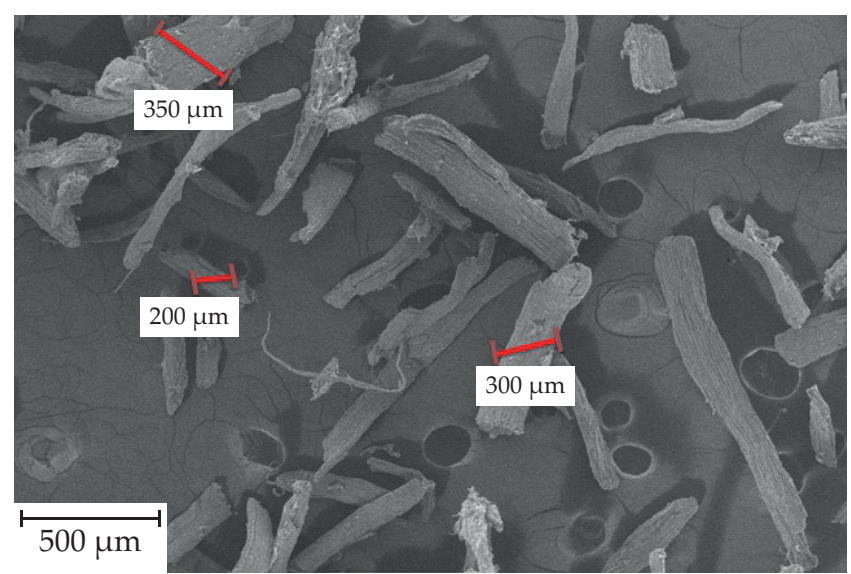

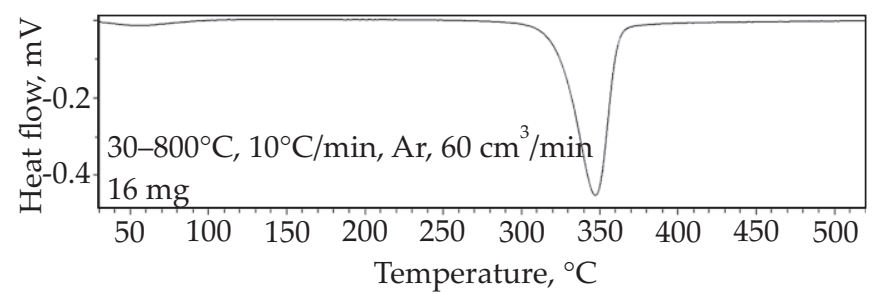

Fig. 4. DTG of the MCC

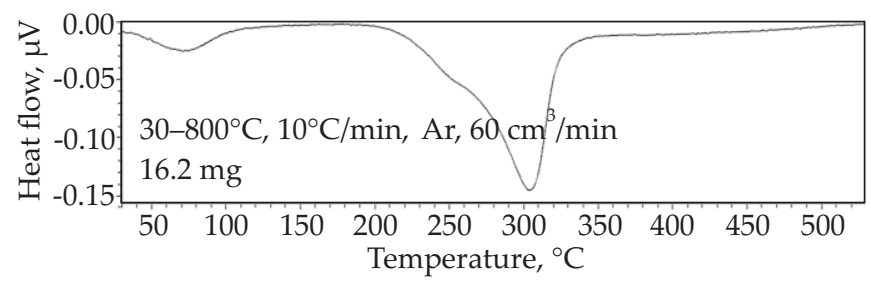

Fig. 6. DTG of the MCC-C

It is typical for the SEM images of coconut husk fiber to have an agglomerate fiber, a large amount of short microfibrils and a non-uniform surface. In the material morphology, a mixture of plated and rod-shaped forms could be seen. Coconut husk fiber defibrillation during alkaline therapy has been demonstrated. Lignin can be extracted, by treating the coconut fiber with sodium chloride, by complex formation and depolymerization. There are some agglomerate elements in the SEM image, as shown in Fig. 7b, because the removal of water from the fiber has not been completely realized. The removal of non-cellulosic constituents can result in a significant decrease in fibril diameter. This may also mean that hemicellulose, lignin, pectin, wax, and other impurities found in the coconut husk have been partially extracted from the non-cellulosic outer layer.

\section{CONCLUSION}

Microcrystalline cellulose from coconut husk residues has been synthesized successfully. XRD shows that all lignin and the bulk of hemicellulose were extracted by

b)

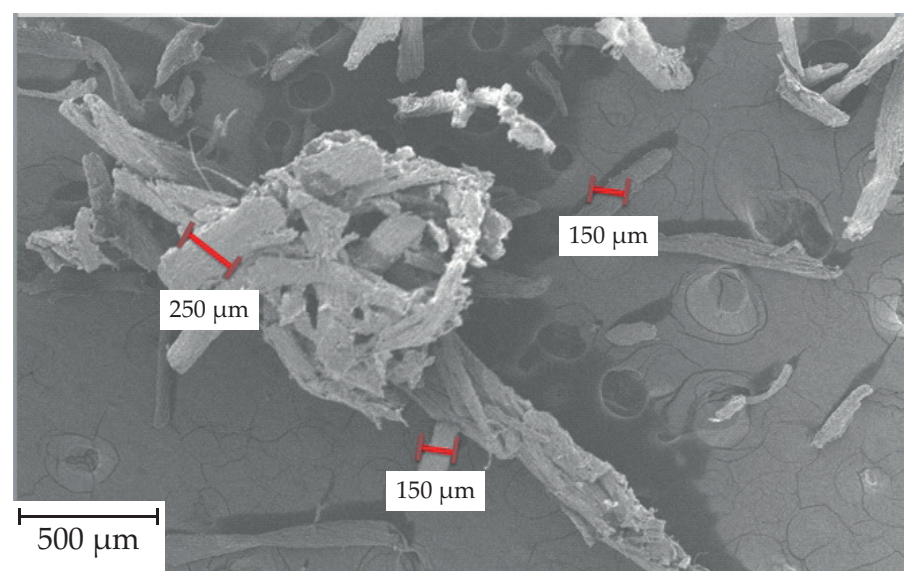

Fig. 7. SEM image: a) MCC, 50×, b) MCC-C, 50× 
chemical treatments. The crystallinity of MCC by $80.15 \%$ and MCC-C by $71.8 \%$ is substantially increased by the chemical treatments. SEM images showed that certain surface impurities, consistent with the removal of wax, pectin, lignin and hemicellulose, could be extracted by chemical treatment, as shown by chemical analysis. TGA found that the chemical treatments damage and increase the degree of crystallinity of the amorphous area of the cellulose. Higher crystallinity values have resulted in higher heat resistance and overall temperature rises for thermal degradation. The cellulose degradation took place at temperature ranging from 300 to $350^{\circ} \mathrm{C}$. The morphology of the fiber confirmed that there is an irregular cross-section, non-uniform surface, a large amount of short microfibrils and some impurities on the surface of the coconut husk fiber. The findings showed that microcrystalline cellulose has been successfully extracted from coconut husk fiber and has great potential in advanced applications.

\section{ACKNOWLEDGMENT}

The authors would like to thank the Centre of Research and Instrument Management (CRIM), UKM, MI-2019-018 and the Ministry of Higher Education of Malaysia, FRGS/1/2019/ TK10/UKM/02/1 for their financial support.

\section{REFERENCES}

[1] Maddahy N.K., Ramezani O., Kermanian H.: Proceedings of the 4th International Conference on Nanostructures (ICNS4), Kish Island, IR Iran, 12-14 March 2012, p. 87.

[2] Naik S.N., Goud V.V., Rout P.K., Dalai A.K.: Renewable and Sustainable Energy Reviews 2010, 14, 578. https://doi.org/10.1016/j.rser.2009.10.003

[3] Ahmad Z., Roziaizan N.N., Rahman R. et al.: MATEC Web of Conferences 2016, 47, 5013.

[4] Rani M.S.A., Mohammad M., Sua'it M.S. et al.: Polymer Bulletin 1.10.2020. https://doi.org/10.1007/s00289-020-03382-2

[5] Israel A.U., Ogali R.E., Akaranta O., Obot I.B.: Songklanakarin Journal of Science \& Technology 2011, $33(6), 717$.

[6] Sabri M., Hafiz F., Shahril K. et al.: Advanced Materials Research 2013, 626, 657.

http://dx.doi.org/10.4028/www.scientific.net/ AMR.626.657

[7] Ali M.: Journal of Civil Engineering and Construction Technology 2011, 2, 189. https://doi.org/10.5897/JCECT.9000009

[8] Arsyad M., Wardana I., Irawan Y.S.: Matéria 2015, 20, 169. http://dx.doi.org/10.1590/S1517-707620150001.0017
[9] Rani M.S.A., Ahmad A., Mohamed N.S.: Polymer Bulletin 2018, 75, 5061. https://doi.org/10.1007/s00289-018-2320-3

[10] Rani M.S.A., Rudhziah S., Ahmad A., Mohamed N.S.: Polymers 2014, 6, 2371. https://doi.org/10.3390/polym6092371

[11] Siró I., Plackett D.: Cellulose 2010, 17, 459. https://doi.org/10.1007/s10570-010-9405-y

[12] Dufresne A.: "Monomers, Polymers and Composites from Renewable Resources" (Eds. Belgacem M.N., Gandini A.), 2008, Chapter 19, p. 401.

[13] Mohamed S.A.N., Zainudin E.S., Sapuan S.M. et al.: "Natural Fiber Reinforced Vinyl Ester and Vinyl Polymer Composites", 2018, pp. 1-25. https://doi.org/10.1016/B978-0-08-102160-6.00001-9

[14] Carvalho K.C.C., Mulinari D.R., Voorwald H.J.C., Cioffi M.O.H.: BioResources 2010, 5 (20), 1143.

[15] Karthikeyan A., Balamurugan K.: NISCAIR Online Periodicals Repository 2012, 71, 627. http://hdl.handle.net/123456789/14634

[16] Azmi M.A.: International Journal of Integrated Engineering 2012, 4 (1), 11.

https://publisher.uthm.edu.my/ojs/index.php/ijie/ article/view/191

[17] Krishnan V.N., Ramesh A.: IOSR Journal of Applied Chemistry 2013, 6, 18.

[18] Reddy K.O., Maheswari C.U., Dhlamini M.S., Kommula V.P.: International Journal of Polymer Analysis and Characterization 2016, 21, 286. https://doi.org/10.1080/1023666X.2016.1147799

[19] Razali N., Hossain M.S., Taiwo O.A. et al.: BioResources 2017, 12 (3), 6773.

[20] Oun A.A., Rhim J.W.: Materials Letters 2016, 168, 146. https://doi.org/10.1016/j.matlet.2016.01.052

[21] Abraham E., Deepa B., Pothan L.A. et al.: Carbohydrate Polymers 2011, 86, 1468. https://doi.org/10.1016/j.carbpol.2011.06.034

[22] Johar N., Ahmad I., Dufresne A.: Industrial Crops and Products 2012, 37, 93.

https://doi.org/10.1016/j.indcrop.2011.12.016

[23] Pickering K.L., Efendy M.A., Le T.M.: Applied Science and Manufacturing 2016, 83, 98. https://doi.org/10.1016/j.compositesa.2015.08.038

[24] Chandra J., George N., Narayanankutty S.K.: Carbohydrate Polymers 2016, 142, 158. http://dx.doi.org/10.1016/j.carbpol.2016.01.015

[25] Rudhziah S., Rani M.S.A., Ahmad A. et al.: Industrial Crops and Products 2015, 72, 133. http://dx.doi.org/10.1016/j.indcrop.2014.12.051

Received 12 XI 2020 